\title{
Public Policy and Administration in the Age of Donald Trump
}

\begin{abstract}
Donald Trump's presidency produced a few legislative victories. Instead, as with his predecessors, the Trump presidency had to rely more on executive orders and other actions to move its agenda. But even this unilateral approach produced fewer results than his supporters hoped for or his detractors feared. This article will examine public policymaking and administration under the Trump Administration. It will argue that while the 2016 electoral victories for Republicans gave Donald Trump an enormous opportunity to move his political agenda, several factors prevented that from occurring.

These factors include indecision on the part of the Trump presidency whether to move a policy agenda or cripple the administrative state; denial of personal responsibility for policies or actions, a failure to understand the constitutional underpinnings of American politics and policymaking, especially when it comes to administrative agency action; intra-party disputes; party polarization; ethical, legal, and impeachment issues; governmental inexperience; and an overall inability to appreciate the differences between the American presidency and business leadership.

Overall, the article describes the political context of the Trump presidency and to explain how it, the structure of American government, and the overall indifference or failure of the Trump administration to understand how the government works rendered this presidency far less effective than it could have been. The lesson of the Trump presidency for the USA and other states is despite rhetoric and claims that outsiders or nontraditional leaders can affect governmental and policy change, they are often ineffectual or dangerous.
\end{abstract}

KEYWORDS: Trump presidency, Public Policy and Administration, Presidential Power, Executive Orders, Ethics, Covid-19, Pandemic, Foreign Policy, Immigration.

RECEIVED 19 July 2021; ACCEPTED 13 September 2021.

\section{INTRODUCTION}

By traditional measures, Donald Trump entered the US presidency as the least qualified person in history. He had never held an elected position. He never held any appointed position in government at any level. He had no foreign or domestic policy experience (Schier and Eberly 2017: ix). He had no training as an attorney or in public policy or administration. His qualification to be president rested in his celebrity status and appeal as an outsider to the government who pledged to drain the swamp in Washington, D.C. (Hughes 2016). In his 2016 Republican Party nomination acceptance speech, he stated that America faced numerous problems, declaring that "Nobody knows the system better than me, which is why I alone can fix it," and that he would "Make America Great Again” (Rucker and Leonnig 2020: 1).

Trump's declared intentions or goals for his presidency were outlined in his July 21, 2016 speech accepting the nomination to be the Republican Party candidate to be president. These goals included repealing the Affordable Care Act, fixing immigration, building a border wall along the US-Mexican border, bringing back manufacturing and reviving the economy, protecting the LGBTQ community from violence, destroying ISIS, reforming tax laws, reforming energy rules, and combating Chinese theft of US jobs and intellectual property, among other promises (Trump 2016). In his January 20, 2017 speech, he again emphasized these themes, also adding to them rebuilding US infrastructure and military capacity (Trump 2017). All these promises set a high bar for how he defined success for himself. Moreover, while for some promises, they involved perhaps weakening the US government, effectively a negative or do-nothing or get-out-of-the-way approach. But in many other cases, they necessitated a strong public administration capable 
of acting and doing things. This included building a border wall or even in undertaking executive action to reverse or eliminate regulations. In effect, his "America first" agenda was not a case of doing nothing, but it required affirmative government action and a competent administrative presidency to achieve it (Thompson, Wong, and Rabe 2020). Largely, though, he failed on these promises and in the opening months of the Biden presidency, Trump's successor has moved rapidly to undo whatever legacy Trump did have.

This article seeks to assess the public administration of the Trump presidency. It does not aim to assess whether his presidency or policies have been good for the USA. Moreover, this article does not seek to politically explain the Trump presidency. By that, the goal is not to assess the political constituencies or interests that his presidency was seeking to benefit or make an argument regarding the deeper political motives of the Trump administration. Instead, the aim is to assess or evaluate his performance as a president and to ask how well he and his administration performed from mostly a public administration perspective. The thesis is that Trump's lack of government experience, along with his own personal style and refusal to come to grips with the reality of an American constitutional system with checks and balances and separation of powers, among other factors, largely rendered his presidency far less effective than his supporters hoped or foes feared. Moreover, while it is common at least for recent presidents to promise government reform or have a philosophy for administrative reform (Schultz and Maranto 1998), Trump did not. The Trump administration largely could be characterized by having no overarching theory of administrative governance.

\section{ASSESSING PRESIDENTIAL POWER}

The starting point to understanding the Trump presidency from a public administration perspective is describing at least generally what powers the US president has. Specifically, can presidents be described as being similar to business leaders or chief executive officers (CEOs) such that the skill set of the latter is similar or good preparation for the former?

Wilson (1989) argues that government is different from business administration in that the former is dictated by constraints upon behavior, while the latter is characterized by the focus on profits and return on investment. Kennedy and Schultz (2010) see a unique ethic or set of values that characterize public as opposed to private or business administration. In general, public administration in democratic societies is focused on promoting accountability to the public and is subject to multiple checks, controls, and constituencies (Schultz and Maranto 1998). Unlike business CEOs, US presidential power is constructed along two dimensions, constitutional and nonconstitutional (informal) forms of authority.

\section{Presidential Constitutional Power: Articles I and II}

The constitutional powers of the President of the United States are defined by America’s Constitution. Specifically, Article II of the US Constitution lists explicit powers of the US president with Congress able to delegate to him additional powers under Article I. While the structure of the US Constitution was supposed to confine the powers of the presidency, it is less clear that this is the case today.

In creating the powers of the US president, the constitutional framers of 1787 had dual visions in mind regarding the power of the chief executive. The first image was that of the king from America's colonial experiences when it was part of the British empire. That was an image of a too powerful king who abused his power. Part of the reason the American colonies sought independence from England is stated in the July 4, 1776 independence, which lists numerous instances of monarchial abuses of power (Becker 1961).

The second image of presidential power comes from America's first Constitution, the Articles of Confederation. Here, the presidency was a short-term rotating office picked by the one-house Congress. This presidency was considered, along with the entire Articles government, to be too weak and ineffective. Thus, when in 1787 delegates were assembled in Philadelphia, Pennsylvania and were originally tasked with revising the Articles, one of the main concerns was not only creating a national government that neither had too much or too little power, but also creating an office of the presidency that similarly achieved this purpose. The fear? Too strong of a presidency would abuse rights. Too weak of a presidency would mean national weakness.

The product of what the constitutional framers produced is described in The Federalist Papers. Written by Alexander Hamilton, James Madison, and John Jay, three supporters of the new Constitution, these 85 essays were addressed to the residents of New York state to encourage them and the state legislature to ratify the new Constitution. Many consider these papers strong evidence of the intent of the framers and a clarification of how the US Constitution was supposed to operate. 


\section{Sciendo}

Alexander Hamilton's Federalist number 70 argues for four ingredients in the new office of the presidency: unity, duration, adequate provision for its support, and competent powers (Hamilton 1937: 455). These four traits would strengthen the president beyond what it was under the Articles of Confederation; yet such powers would still be consistent with republican or popular government. Several reasons were offered across The Federalist Papers to show why presidential power need not be feared. One, the president as well as the entire Constitution would be read as a power-conferring document. By that, unless otherwise specified in the Constitution, there would be no implied powers for the federal government or president to act (see Federalist no. 17 and 84). Two, the presidency will be inferior to Congress in its powers (Federalist no. 48; Hamilton 323). Finally, drawing upon Baron de Montesquieu, the new Constitution would contain the principles of separation of powers and checks and balances as a mechanism to contain the power of all branches of government, including that of the president. As stated in Federalist no. 47:

From these facts, by which Montesquieu was guided, it may clearly be inferred that, in saying "There can be no liberty where the legislative and executive powers are united in the same person, or body of magistrates," or, "if the power of judging be not separated from the legislative and executive powers," he did not mean that these departments ought to have no PARTIAL AGENCY in, or no CONTROL over, the acts of each other. His meaning, as his own words import, and still more conclusively as illustrated by the example in his eye, can amount to no more than this, that where the WHOLE power of one department is exercised by the same hands which possess the WHOLE power of another department, the fundamental principles of a free constitution are subverted. This would have been the case in the constitution examined by him, if the king, who is the sole executive magistrate, had possessed also the complete legislative power, or the supreme administration of justice; or if the entire legislative body had possessed the supreme judiciary, or the supreme executive authority. (Hamilton 314)

Presidential power in the USA was supposed to be circumscribed significantly by a constitutional structure that limits chief executives to powers prescribed in the Constitution.

US presidential power is defined in Article II of the Constitution. This article prescribes three major presidential powers along with a host of secondary powers. Article II, section I vests executive power in the president. This clause, along with Article I, section I and Article III, section I, which vest legislative and judicial powers in Congress the Supreme Court, respectively, are known as the vesting clauses. These three clauses embody the concept of separation of powers. Article II, section 2 provides for the president to be commander-in-chief of the armed forces; Article II, section 3 declares that the president shall "take care that the laws be faithfully executed" ("Take care" clause). These three clauses are the broad general grants of presidential power, making the president the chief executive, civilian head of the military, and the chief law enforcement official. Article II also assigns specific powers to the president, including vetoing legislation, making treaties, issuing pardons, and appointment of ambassadors, judges, and other officers of the USA. Collectively, one can refer to all these as Article II powers of the president.

But in addition to Article II powers that the Constitution assigns to the president, Congress can grant to him additional powers under Article I. In Schechter Poultry v. United States, 295 U.S. 495 (1935), the issue of delegation of power was tested. The Court ruled that so long as Congress delegated authority to president to act in ways that constrained wide open discretion, there would be no violation of Article I, section 1. In sum, as what has come to be known as the intelligibility principle, delegation is permitted so long as with certain bounds. Exactly what those bounds are practically is not clear because ever since Schechter, no delegation has been struck down as unconstitutional.

The ability of Congress to delegate additional power to the president has implications on the checks and balances and separation of powers issues. Article I contains a host of powers for the legislative branch that serve as checks on the presidential authority, but also delegation suggests a complex relationship between presidential and congressional power.

Youngstown Sheet and Tube v. Sawyer (343 U.S. 579, 1952), also known as the "Steel Seizure" case, may be one of the most influential cases on foreign policy and, in general, presidential power in the Court's history - at least it has become so. While the Court struck down President Truman's effort to nationalize the steel industry to avert a strike and the interruption of steel production during the Korean War, the case is not read as detrimental to presidential power and authority. The various opinions describe the legal scenarios that might support significant presidential power in foreign policy matters, or at least the issues that take place beyond US borders. It is important to read the opinion as providing an outline for what types of foreign policy authority the president does have.

Most importantly, Justice Jackson's opinion is often the most cited part of the Youngstown decision. It describes a tripartite division of presidential power in foreign affairs depending on whether the chief executive is acting alone or with or against congressional approval. What Youngstown constitutionally establishes is the proposition, along with Schechter, that Congress may add to Article 
II presidential power by delegating to it Article I powers. In many ways, the delegation of additional powers to the president is at the heart of the administrative or New Deal state, whereby the executive branch is given additional regulatory or other powers. But conversely, Youngstown also indicates that presidents are vested with certain inherent powers that Congress may not encroach upon, and that the legislative branch may impose some limits on executive branch actions.

Overall, when it comes to presidential power, the Constitution indicates that presidents obtain their authority either from Article II of the Constitution or may be delegated some additional authority from Congress via Article I. There are no extratextual constitutional powers for the president. Finally, presidents are subject to constitutional limits on their authority, with these limits captured by the phrases checks and balances and separation of powers. Unlike the private bureaucracies which may be characterized by their unitary top-down power structures, the US federal bureaucracy is not so constituted (Schultz and Maranto 1998).

\section{Informal Powers}

The Constitution defines the formal powers of the president. Scholars such as Barber (1972), Neustadt (1964), Goodwin (2018), Edwards (2016), and Burns (2010) have located the strength and efficacy of US presidents in part to their personalities or other institutional arrangements such as the size of the congressional majorities or public support. Others such as Skowronek (2008) see presidential power defined by time and circumstances of history, while some others see leadership style as a defining element of real presidential authority.

The point these presidential scholars is making that that for the most part, all presidents, including Donald Trump, have roughly had the same constitutional power, yet some have been more effective in governing and moving their agenda than others. Historians compile lists that rank and rate the best and worst presidents, judging them in part along dimensions that capture their ability to secure their policy agenda. Richard Neustadt famously captured this notion in arguing that the real power of the presidency is the power to persuade. Presidents, because of the constitutional constraints on their authority, cannot simply order or command others to act, much like a monarch, dictator, or military general might. Often, they must bargain or cajole others to act. Factors identified as critical to the power to persuade might be their personal style or personality, historical opportunities, strength and size of congressional majorities, public opinion, and media skills. Some presidents might see their role as more transactional versus transformational too (Burns 2010).

Thus, real presidential authority is constitutional authority plus the power to persuade and historical context. In the context of public administration, approximately the same equation exists. By that, to evaluate presidential public administration effectiveness, one needs to look at how well they have mastered the constitutional context of the office and combined that with persuasiveness and historical context.

\section{TRUMP'S PUBLIC ADMINISTRATION}

\section{Context}

As noted in Section "Introduction," the Trump presidency did have stated goals that demanded an effective administrative capacity. These goals included building a border wall, reforming energy policy, immigration reform, and bringing back manufacturing jobs. These and other goals demanded administrative capacity in terms of moving legislation or mastering the art of administrative law in order to change rules or issue executive orders. Had he run a competent executive department, he might have been more successful than he was in securing these objectives.

Donald Trump assumed office with several factors augmenting and constraining his presidential public administration authority. On the plus side, first, Trump had congressional majorities in both the House and the Senate, giving him significant capacity to move his policy agenda and secure appointment of key staff in his administration. Second, Trump also benefitted from recent federal legislation that allowed for him to begin presidential transition planning earlier than allowed for by previous presidents. Third, Trump had command of the social media and was able to use his years of television personality experience to help him with securing public support. Fourth, his political base was solidly behind him and has remained so into his fourth year in office. Finally, as someone who 
had a famous bestselling book The Art of the Deal, one would have presumed he would have been able to use the power of persuasion effectively.

Conversely, the president did not win the popular vote and had secured a narrow electoral college victory. He took office with high disapproval ratings that persisted throughout his presidency, and Trump himself had no government experience to draw upon. Also, according to at least one psychologist, he did not bear the personality characteristics typical of US presidents (Schier and Eberly 27). In short, Trump's political capital was less than his supporters hoped or his opponents feared (Schier and Eberly 57). Finally, according to Rucker and Leonnig (2020), Trump's personal administrative style was a major source of his problems.

\footnotetext{
Yet Trump's own recklessness hampered his ability to accomplish the very pledges on which he campaigned. From the start, government novices and yes-men made up much of his inner circle, a collective inexperience that exacerbated the troubles, wasted political capital, and demoralized committed public servants. The universal value of the Trump administration was loyalty-loyalty not to the country but to the president himself (2).
}

This recklessness, a belief he knew better than experts, and his simple denial of personal responsibility for policies or actions, all would characterize the administrative style of the Trump presidency and serve also as a major factor limiting its efficacy.

\section{Personnel Issues and the War on Government}

Turbulence might be the first word or characteristic to describe Trump's public administration record. Even though the 2010 Presidential Transition Act gave him ample opportunity to prepare to take office, his transition set the tone for his entire presidency. Originally, his son-in-law Jared Kushner was to head the transition, and then it shifted to former New Jersey governor Chris Christie, and then he was ousted. This constant changing of transition chiefs foreshadowed similar problems Trump has had as president. For example, his original chief of staff Reince Preibus lasted 6 months, to be replaced by General John Kelly who lasted 18 months, to be replaced in early January 2019 by Mike Mulvaney as acting chief of staff, only to be replaced by Mark Meadows. The Trump administration also had an unprecedented number of appointees replaced, fired, or resigned, causing problems in continuity of leadership. Many positions went unfilled or simply were staffed with acting personnel (Schier and Eberly 70; Kassop 2019; Goodsell 2019). In 2020, Trump also sought to abolish civil service protections for tens of thousands of federal workers, underscoring the conflicts his administration has had with careerists (Rein and Yoder 2020).

Moreover, while it is not unusual for presidential appointees and the careerists to have conflicts, the degree to which there had been friction between the two is also atypical. Right from the start, the Trump administration caused friction with the bureaucracy by delaying pay raises, freezing hirings, and transferring member of the Senior Executive Service, such that many resigned (Goodsell 2019).

But equally as important to the personnel issues, there was a general ambivalence to the federal government. Steve Bannon, one of Trump's original political and policy advisors, noted the skepticism or conflict between them, bemoaning how the "deep administrative state" was seeking to undermine the president. Such a skepticism was fueled in part by pieces such as the famous New York Times Anonymous $(2018,2019)$ author talking about leading the resistance against the Trump presidency.

Several accounts by Woodward (2020), Anonymous (2018, 2019), and Wolff (2018), among others, simply describe the turbulence and incoherence within the Trump administration. The president refused to read policy or intelligence briefings (Goodsell 875), preferring to go with his gut or changing his mind at whim. He deeply distrusted many of the careerists, especially those who were holdovers from the Obama administration. Trump refused to learn from his time in office, failing to correct previous governing mistakes, perhaps still thinking that he is the CEO of the government and that neither the constraints of the Constitution nor the lessons of persuasion that Neustadt described hold. While all presidential administrations have learning curves, the Trump presidency seems to have eschewed it, with some declaring over time that he preferred governing or directing on his own while ignoring all advice from the staff or other agencies (Woodward 2020).

The turbulence issue is thus closely related to either a competency, leadership, or ideological issue. By that, Trump's lack of government experience and his unwillingness to learn, while perhaps popular with his base, hamstrung his ability to govern. There was no clear sense of an overall Trump administrative agenda, or at least a coherent one, unless one sees it in efforts simply to repeal all things that Obama brought, including his Affordable Care Act. Some have remarked that the Trump presidency was actually 
"anti-administration" (Goodsell 2019), undermining agency mission, rejecting science (when it comes to global warming or other environmental issues), or otherwise letting the president's personal interests or ideology stand in the way of effective administration.

Incompetence defined his administration and compromised Trump's ability to secure the goals he outlined in his party acceptance and inaugural speeches. But there was a counter movement within Trump's public administration. Steve Bannon, as noted above, wanted to smash the administrative state. He was simply anti-government and long after Bannon left, the Trump administration this animus or attitude persisted. This mashing of government came into conflict with using the state and administrative apparatus to move a conservative public administration and policy agenda (Michaels 2017). Even Ronald Reagan, criticized for the conflict he had with the federal bureaucracy, eventually understood the need of co-opting or using it to govern. Trump never recognized that. His effectiveness as a president and his presidency overall could have been far stronger had it opted to use the administrative state to govern and move an agenda, as opposed to weakening or fighting it. Thus, while others have emphasized that the Trump administration was simply noted for its anti-government management style which sought to disable the executive branch (Goodsell 2019; Kassop 2020; Schier and Eberly 2017), it is more accurate to argue that the incompetence in the ability to use the administrative powers to accomplish policy goals came into conflict with the desire to disable the state. The conflict perhaps forever doomed the ability of the Trump administration to succeed along the dimensions it aspired to achieve.

\section{Administrative Procedures Act}

Presidents, as noted above, have two sources of constitutional or legal authority, that which is granted to them by Article II of the Constitution and that which is delegated to them by Congress though the latter's Article I authority. When presidents act under Article II authority, they have far more power than when acting under Article I delegated power. In the latter case, Congress may attach more strings or limits to what the president or the executive branch does. They may do that through their appropriations authority or from other clauses in the Constitution.

When Congress delegates authority or to the executive branch, in theory, there are outer limits to how far it may go. In Schechter Poultry, the Court argued that legislative authority cannot be delegated in a wholesale fashion and that some limits on executive branch discretion must be imposed. This is especially the case when Congress delegates to the president, the executive branch, or one of the administrative agencies rulemaking authority. The problem of congressional delegation of rulemaking authority is a product of interest group politics, the increasing complexity of technical rules and expertise, and simply, divisions of labor. The issue of delegation was not anticipated by the US constitutional framers, who, in 1787, did not anticipate the rise of the administrative or regulatory state. But by the time of US New Deal under President Franklin Roosevelt in 1933, accommodating the regulatory state with the original constitutional concepts of checks and balances and separation of power became a major problem. Numerous Supreme Court cases sought to sort this out, as did the eventual adoption in 1946 of the Administrative Procedures Act (APA).

The APA outlines the rules under which when Congress has delegated rulemaking or adjudication authority, the executive branch, the administrative agencies, or the president must follow. There must be limits on discretion when agencies such as the Environmental Protection Agency (EPA) issue rules regarding clean air, water, or emissions, for example. These rules require specific steps to be followed, including notice, and allowing for public participation and comment ("notice and comment"). Rule must also provide for statements of need and evidence to support them as well as response to objections to them. Similarly, adjudication has a set of rules, but they also implicate constitutional due process issues if the decisions do not follow specific procedures.

Together, if federal agencies, the executive branch, or the president via executive orders act under Article I delegated powers, there are constraints on their behavior. Rules or executive orders issued under this delegated power under the APA carry the force of law. This also means efforts to change these rules must follow a similar process. Rules once promulgated cannot simply be changed for political reasons; there must be substantial evidence to support their changes and the changes must a process.

The reason why this brief discussion of the APA and administrative law is important is because so much of what presidents do, and what public administration is about, takes places with rulemaking and increasingly, executive orders by presidents of the USA. Administrative rulemaking, including presidential executive orders, often goes hand in hand with the normal legislative process to make law.

A defining characteristic of American politics over the last 30 years has been the increased political polarization and partisanship (Binder 2003). This polarization has made it more difficult to enact laws, especially if there is split party control of the two houses of Congress or with the president. This polarization has helped undermine presidential effectiveness and public administration. 
Consider the first year of the presidencies of Bill Clinton (1993), George Bush (2001), Barack Obama (2009), and Donald Trump (2017). For each of them, there was single party control of the presidency and both houses of Congress in their first year (in the first half year for Bush in 2001). Theoretically, this means the president should have had the easiest time to pass legislation not only because of the partisan makeup, but also that is often when presidents enjoy their greatest popularity and their political capital is at their highest. Clinton in his first year saw 209 bills signed into law; for Bush, it was 102, Obama 118, and Trump 94 (GovTrackUS 2017; Jacobson 2018). Of the last 10 presidents, Trump comes in last in terms of the number of bills signed into law.

Certainly, though, the paucity of bill should perhaps not be a single measure of presidential public administration effectiveness, especially in an era of partisan polarization. Often, presidents have resorted to the use of executive orders to act when they are unable to get their way with Congress.

As a candidate, Trump criticized President Obama for resorting to executive orders to govern, seeing them as a sign of weakness. However, consider Table 1 which looks at the number of executive orders issued under presidents Trump, Obama, Bush, and Clinton (Federal Register 2021).

Tab. 1: Presidential Executive Orders.

\begin{tabular}{lll}
\hline President & First term EO & Total EO \\
\hline Trump & 219 & 219 \\
\hline Obama & 147 & 276 \\
\hline Bush & 171 & 291 \\
\hline Clinton & 178 & 304 \\
\hline
\end{tabular}

Several things stand out. Trump issued more executive orders in his only term than did his predecessors in their first year. In fact, in his first year, Trump issued 55 executive orders, compared to 38, 54, and 57 issued by Obama, Bush, and Clinton, respectively. Trump used them heavily even in the first year when his party had control of both houses of Congress (Federal Register 2021). Trump seemed no more or less likely to resort to executive orders to act than did his recent predecessors and, if their use was a sign of Obama's weakness or ineffectiveness, the former's issuance of 72 more executive orders than the latter (comparing Trump's presidency to Obama's first 4 years) perhaps speaks to his weakness as a public administrator.

However, the number of executive orders may still not be a fair indication of public administration skills. What also might count is what these orders have done and whether they have survived legal scrutiny. While some of Trump's major executive orders such as the Muslim travel ban were upheld by the Supreme Court in Trump v. Hawaii, the fates of many of his orders have not been so good. The Washington Post (Barbash and Paul 2019) pointed out that the Trump administration has lost 63 cases in court simply because of its failure to follow the basic rules of the APA and administrative law. It thought it could simply issue rules or executive orders that rescinded or changed previous rules or orders without following process and procedure.

Kassop (2019) classified four types of legal challenges to Trump policies - immigration, limits on rights (e.g., for transgenders), Obama-era rules (mainly environmental), and terrorist detention - finding that the president has sustained many losses. Additionally, his efforts to add citizenship status to the 2020 Census were negated (Hurley and Chung 2019) and the courts have tied up for a long time much of his effort to reallocate funds under the National Emergencies Act to build a border wall (Merchant and Freking 2020), and whether he will be able to sustain his efforts to undo rules regarding DACA (Barnes 2019) and auto fuel and emission standards for California are still up in the air (Shepardson 2019). Additionally, efforts to undo Obama-era designations if historic monuments under the Antiquities Act have been limited (McCombs 2019).

Overall, while the New York Times reported that as late as December 2019, Trump was preparing to roll back 95 environmental rules (Popovich 2019), various reports indicate that between $70 \%$ and $85 \%$ of previous efforts have been overturned in the courts (Earth Justice 2020; Sexton 2019). If effectiveness in public administration is measured in part by securing judicial endorsement and subsequent administrative enforcement of one's agenda, then that is not occurring with the Trump administration. Bills were not being signed into law and executive orders were not passing legal muster. 


\section{ETHICS, RUSSIA, AND IMPEACHMENT}

Another characteristic or factor impacting the Trump public administration legacy can be lumped into a package of controversies surrounding the ethical and legal conduct of the administration.

First, dating from the presidential campaign, into the transition, and then throughout the presidency, the Trump administration faced charges regarding its involvement with Russian interference in the 2016 presidential election. The results of these allegations were both congressional hearings and investigations into possible Russian involvement (which largely concluded yes) and the eventual appointment of a special investigator Robert Mueller in 2017 by an Assistant Attorney General. The Muller investigation (Muller 2019) took more than 2 years to complete, during which it involved several indictments and convictions or pleas by individuals associated with the Trump campaign. The overall Mueller report, released in 2019, concluded that Russians did interfere with the 2016 US elections, but that there was insufficient evidence to conclude that the Trump campaign had aided and abetted in those efforts. The report also looked at whether President Trump had sought to obstruct the special prosecutor's investigation. While the report did highlight 11 possible instances of obstruction of justice, the final report declared that it could neither rule out that obstruction had occurred nor that there was sufficient evidence to indict him. The latter conclusion, to a large extent, was also premised upon long-standing Department of Justice opinions that a sitting president could not be indicted for a crime.

The ongoing Russian interference investigations dominated the first 3 years of the Trump presidency. They also produced collateral investigations by the US Attorney's Office in Manhattan, New York, as well as by the Manhattan County Attorney into other questions including whether the president's personal attorney Michael Cohen had made illegal payments to an adult film star during the 2016 presidential race in order to discourage her from discussing an affair she had with Donald Trump. Eventually, Cohen pled guilty to those charges.

But beyond the Russian interference and Michael Cohen matter, issues of questionable illegality and ethics continued to plague the Trump administration, clearly in ways that consumed time and resources, and therefore distracted this presidency from performing its administrative functions. For example, Trump faced litigation personally involving his own charity that he operated in New York and was eventually forced to pay a fine and cease its operations. He also settled claims regarding Trump University. Concerns about how he mixed his personal Trump business enterprises with his presidency have led to lawsuits claiming violations of the Constitution's Emolument clause. Efforts by Congress and New York to obtain his personal tax records were part of investigations tied not only into his connections with Russia, but also about concerns of conflicts of interest and perhaps fraud in his business dealings. The point is that Trump himself had to address many issues that raise questions about his own ethical conduct in office, which itself is an issue; also, addressing the allegations distracted him from performing public administration activities.

But ethical and legal problems were not limited to the president. Bloomberg News (2019) documented numerous scandals in the Trump administration. The Washington Post (Bump 2019) too has maintained a list. The list includes individuals who worked for or with Trump, in his administration, and associates (Beckwith 2019).

Additionally, Trump officials have faced questions regarding ethics and legal violations. Kellyanne Conway, a presidential advisor to Trump, was deemed to have violated the Hatch Act ban on partisan activities more than 50 times according to the US Office of Special Counsel. The office recommended her dismissal, and the president took no action (Baker 2019). There were allegations that special accommodations were made in violation of the law to grant a security clearance to Donald Trump's son-in-law Jared Kushner, but again no action was taken. Finally, concerns about other Trump officials engaging in self-dealing or having conflicts of interest too pervaded the Trump administration. For a president who pledged to "drain the swamp" in Washington, D.C., the multiple indictments and ethics allegations raise serious questions about the overall public administration ethics of the Trump administration.

Finally, dominating the second half of Trump's third year and going into his fourth were two articles of impeachment growing out of a July 25, 2019 call the president had with the president of Ukraine. The charges allege abuse of power in seeking President Zelensky's help in doing or announcing an investigation of Trump's main political rival in the 2020 presidential election (former Vice-president Joe Biden) and efforts to obstruct congressional investigation of this call. On essentially a straight party-line vote, in December 2019, Trump was changed with two articles of impeachment, abuse of office and obstruction of Congress (Shear and Baker 2019). Subsequently, on February 5, 2020, the Senate acquitted the president of these two articles of impeachment (Baker 2020).

The impeachment along with this faceoff with Congress yet again consumed significant amount of Trump administration's time, energy, and political capital. Post-acquittal, the impeachment process had several legacies for public administration under Trump. One, it worked to vindicate, at least in theory, that Trump had not done anything wrong. Two, it led him to begin a purge 
of members of his administration whom he perceived were disloyal. Three, it led to an embroiling of Attorney General William Barr into controversies regarding how politicized he or his department was in terms of its independence, especially in light of the president claiming that as "chief law enforcement officer" of the USA, he could do whatever he wanted in terms of Justice Department, including issuing pardons or taking retaliatory action against perceived enemies (Olorunnipa and Reinhard 2020). The overall point is that after the Senate trial, the Trump administration did not move beyond the personnel or organization problems it appeared to have before it, rendering it as ineffective or disorganized as it was before the trial.

But Trump's 2020 impeachment acquittal was not his only one. On January 6, 2021, as the electoral votes were being counted in Congress, Donald Trump gave a speech to his supporters that many considered to be inciting a riot. In the closing days of his administration, the House impeached Trump a second time, which was followed by a second Senate trial and acquittal after he left office. While this second impeachment was politically and historically significant, the impact on the actual performance of his government and administration with 2 weeks left (and of course, with the trial after he left office) was little. Perhaps his speech encapsulates the fact that Trump never appreciated the role he occupied in the government as president and what his office and administration could do to impact others.

\section{COVID-19}

The last assessment of the public administration of Donald Trump must center on Covid-19 and his handling of the coronavirus pandemic. In November or December 2019, news broke that a new virus was spreading in the Wuhan Province of China. At first, information regarding its morphology and seriousness was not well understood or communicated, with some arguing that China was not providing sufficient information and data on it. Subsequently, into early 2020, the Trump administration was unsure how to respond. As the coronavirus spread to the USA in January and February 2020, the president was focused on his impeachment and the Senate trial. Then, after his acquittal in February 2020, the president turned to his re-election campaign and, as noted above, getting even with perceived enemies whom he did not view as sufficiently loyal. By March, potentially viewing the virus as a possible problem for his campaign, the president himself simply downplayed the virus (Anon 2020). At times, he dismissed it as not too serious of a health measure, or simply denounced it as the "China virus" as a way of shifting blame on to others (Chiu 2020). He also denied responsibility for the virus' spread (Oprysko 2020).

For the remainder of the Trump presidency, the handling of the pandemic became emblematic perhaps of the entire presidency. Mixed messages and missed opportunities were the story of 2020. The president himself denied the reality of the virus, while the Centers for Disease Control (CDC) and mostly famously, Dr. Anthony Fauci, the president's medical advisor and part of the White House Coronavirus Task Force, dueled with the president (Lantry and Ebbs 2020). Fauci, along with Deborah Birx, were publicly often at odds with Trump at press conferences regarding how to handle the pandemic. They disputed over the seriousness of the pandemic, wearing of face masks, closing of the economy, and other measures to contain the spread of the virus (Lantry and Ebbs 2020). Confusion, delay, and politicization at the CDC and in the Trump administration overall led to what some see as a lost month in February 2020 where, had the president acted more quickly, perhaps the virus could have been contained or slowed (Shear 2020). Allegations surfaced that the administration mishandled the distribution of medical supplies to the states or that it simply did not act or cooperate (Bender and Ballhaus 2020). At one point, Trump, when he sort of recognized the seriousness of the pandemic, suggested his administration would have done a good job if only 200,000 died (Derysh 2020). Conversely, as Woodward (2020) pointed out, Trump admitted to lying to the public about the seriousness of the pandemic, ostensibly to forestall a panic.

The Trump administration, instead of seeking to develop measures to mitigate the spread of the virus, sought to bank on finding a rapid vaccination. "Operation Warp Speed" was the program funded by the US government to race for a vaccination and fund distribution for inoculations (McEvoy 2021). The hope for Trump was that announcing a vaccine before the 2020 presidential election would overcome any damage to his election prospects by the pandemic. His administration should get credit for working for a quick development of the vaccine, but it is not clear how much credit goes to the government or the pharmaceutical companies. However, public opinion polls suggested that he and his administration did not receive high marks for the handling of the pandemic, and this is probably what cost him his re-election (Kendall 2020). Thus, if in part, one goal of his first term was securing re-election, the general incompetence of his administration cost him that goal. Finally, after the election, as the vaccines became available, many argued that the administration failed to provide the coordination needed to oversee their distribution to the states and health-care 
deliverers (Reuters Staff 2021). By the time Trump left office on January 20, 2021, relatively few vaccines had been administered, leaving it to the Biden administration to fix the implementation and delivery issues (Reuters Staff 2021).

\section{CONCLUSION}

The presidency of Donald Trump was largely defined by several characteristics when it came to public administration. One, unlike many recent presidents where there had been some overarching public administration theory, there was none with the Trump presidency. This lack of theory has meant that while there were Trump policy initiatives, there were few goals when it came to administration of them by the executive branch. There was no real call to improve efficiency, service delivery, or enhance performance of the bureaucracies. In fact, the criticism of the "deep state" belies disregard of administrative staffing, procedure, and structure. It also points to how he sought to disable the national government. This lack of administrative goals, the president's denial of responsibility for is actions, along with a paucity of experience and indifference to government service and constitutional norms rendered the Trump presidency far less effective in terms of its capacity to govern and execute policy than it could have been. Yet, while Trump waged a war on the national government, he needed a competent public administration to achieve many objectives. Incompetence and explicit choices to hinder the administrative state came into conflict with his needs to use it to secure critical goals, including combating the pandemic.

In addition, the Trump presidency was marked by significant ethical issues, disorder caused by the impeachment process, the pandemic, and other personnel problems stemming from what could be described as a pathos of resentment or personalization of the presidency in Donald Trump that subjected the executive branch to the whims of his personality. The simple takeaway from a review of the public administration philosophy or practice of the Trump administration was that there was no coherence to either of them.

Trump's approach to public administration damaged the effectiveness of his ability to govern and the ability of the bureaucracy to perform. The question is whether after one term under Trump, his performance inflicted lasting damage to the federal government in terms of staffing, morale, and general capacity to operate. This, of course, is difficult to determine. However, as Joe Biden took over in 2021, he issued many executive orders reversing those of Trump. He began the process of straightening out the vaccine distribution problems, and his appointment of experienced Washington insiders demonstrated early on a contrast in style and an effort to repair the damage to public administration done by Donald Trump. Whether Donald Trump was an outlier in US presidential leadership and direction, or whether he forged a new path for America will be determined soon.

Some might argue that a narrow focus on the public administration capacities of the Trump administration could miss some more fundamental issues. By that, one argument may be that the apparent incompetence of the Trump presidency was by design, an effort to purposively sabotage the capacity of the federal government to perform. Yes, the failure to fill critical positions was, as noted, part of an effort to disable the government. By those who argue that the Trump presidency orchestrated incompetence place far too much credit in the administration in terms of being able to essentially affect or fake incompetence. Moreover, such a claim also ignores, as pointed out here, that if, in fact, the Trump presidency did wish to secure some goals that favored particular constituencies, it needed the government to have the capacity to perform and do its job. This is the case especially with the border wall and efforts to repeal environmental rules. The Trump administration both, as pointed out here, needed the government and the bureaucracy to secure desired goals, while at the same time its real incompetence damaged that effort.

A second argument may be that the stories of incompetence, including the handling of the pandemic, were sideshows or diversions from more important issues. In effect, incompetence was a "Wag the Dog" phenomenon, a reference to a 1997 American film where a fictional president starts a war to divert attention from a personal scandal impacting his re-election. Again, such a claim requires showing of competence of the Trump presidency to coordinate this diversion, and it also fails to substantiate what the "real issues" were that this affected incompetence was meant to divert one from seeing. There may have been subtexts to many actions within the Trump administration, but by ostensibly and narrowly focusing on the administrative performance of the Trump presidency, we learn something important about why, why not, and how it secured or failed in its objectives, and perhaps also failed to serve the interests that it needed to win re-election.

Finally, the lesson of the Trump presidency for the USA is despite rhetoric and claims that outsiders or nontraditional leaders can affect governmental and policy change, they are often ineffectual or dangerous. Within the USA, there is the aura or belief that outsiders are needed to fix the problems of Washington, D.C. and the national government. What the Trump presidency tells us 
about the USA and democracy is that strong executives are important, but there is a fine balance in authority. It is not only important to have presidents or leaders with sufficient skills to lead, but also they need the moral compass to lead in the right way. The Trump presidency should serve as a warning to the USA and the rest of the world regarding singularly the importance of US presidents and leadership in the world, but more generally regarding what we learn about what happens when political novices, outsiders, or populists take charge. Thus, the presidency of Donald Trump not only speaks about the presidential power within the USA, but perhaps is also a warning for other states across the world that may wish to elect novices or outsiders to office.

\section{REFERENCES}

Anon. 2020. "40 times Trump said the coronavirus would go away," Washington Post. Located at https://www.washingtonpost.com/ video/politics/40-times-trump-said-the-coronavirus-would-goaway/2020/04/30/d2593312-9593-4ec2-aff7-72c1438fcaoe_video.html (site last visited on May 11, 2021), November 2.

Anonymous. 2019. A Warning. New York: Hachette.

Anonymous. 2018. "I Am Part of the Resistance Inside the Trump Administration," New York Times. September 6, A:23.

Baker, Peter. 2020. "Impeachment Trial Updates: Senate Acquits Trump, Ending Historic Trial." New YorkTimes. Located at https://www.nytimes. com/2020/02/05/us/politics/impeachment-vote.html. (Site last viewed on February 25, 2020), February 6.

Baker, Peter. 2019. "Trump Is Urged to Fire Kellyanne Conway for Hatch Act Violations," New York Times Located at https://www.nytimes. com/2019/06/13/us/politics/kellyanne-conway-hatch-act.html (Site last visited on January 28,2020 ).

Barbash, Fred and Deanna Paul. 2019. "The real reason the Trump administration is constantly losing in court," Washington Post, March 19, A1.

Barber, James David. 1972. The Presidential Character: Predicting Performance in the White House. Prentice Hall.

Barnes, Robert. 2019. "Trump administration defends ending DACA, and Supreme Court's conservatives seemed receptive," Washington Post. Located at https://www.washingtonpost.com/politics/courts_law/ trump-administration-tells-supreme-court-it-owns-termination-ofdaca-program/2019/11/12/2ac4f4ea-0545-11ea-b17d-8b867891d39d_ story.html (site last visited on February 25, 2020), November 12 .

Becker, Carl L. 1961. 61. The Declaration of Independence: A Study in the History of Political Ideas. New York: Vintage.

Beckwith, Ryan Teague. 2019. Here Are All of the Indictments, Guilty Pleas and Convictions From Robert Mueller's Investigation, Time. Located at https://time.com/5556331/mueller-investigationindictments-guilty-pleas/ (Site last visited on January 28, 2020).
Bender, Michael C., and Rebecca Balhaus. 2020. "How Trump Sowed Covid Supply Chaos. 'Try Getting It Yourselves,"' Wall Street Journal. Located at https://www.wsj.com/articles/how-trump-sowed-covidsupply-chaos-try-getting-it-yourselves-11598893051 (site last visited on May 11, 2021), August 31.

Binder, Sarah. 2003. Stalemate: Causes and Consequences of Legislative Gridlock. Washington: Brookings.

Bloomberg. 2019. Trump Team's Conflicts and Scandals: An Interactive Guide Located at https://www.bloomberg.com/graphics/trumpadministration-conflicts/ (Site last visited on January 28, 2020), March 14.

Bump, Philip. 2019. A list of the alleged and admitted crimes undertaken by people associated with the Trump campaign, Washington Post. Located at https://www.washingtonpost.com/politics/2019/01/25/ list-alleged-admitted-crimes-undertaken-by-people-associated-withtrump-campaign/?arc404=true (site last visited on January 28, 2020), January 25 .

Burns, James M. 2010. Leadership. New York: Harper.

Chiu, Alison. 2020. "Trump has no qualms about calling coronavirus the 'Chinese Virus.' That's a dangerous attitude, experts say," Washington Post. Located at https://www.washingtonpost.com/nation/2020/03/20/ coronavirus-trump-chinese-virus/ (site last visited on May 11, 2021), March 20.

Derysh, Igor. 2020. "Trump says he will do "a very good job" if only 200,000 people die in US from COVID-19, Salon. Located at https:// www.salon.com/2020/03/30/trump-says-he-would-do-a-very-good-jobif-only-20000o-people-die-in-us-from-covid-19/ (sgte last visited on May 10, 2021), March 30.

Earth Justice. 2020. "When We Win." Located at

https://earthjustice.org/features/environmental-lawsuits-trumpadministration (Site last viewed on January 28, 2020)

Edwards, George C. 2016. Predicting the Presidency: The Potential of Persuasive Leadership. Princeton: Princeton University Press. 
Federal Register. 2021. Executive Orders. Located at https://www. federalregister.gov/presidential-documents/executive-orders (site last visited on May 10, 2021)

Goodsell, Charles T. 2019. "The Anti-Public Administration Presidency: The Damage Trump has Wrought." Annual Review of Public Administration. Vol. 49(8): pp. 871-883.

Goodwin, Doris Kearns. 2018. Leadership in Turbulent Times. New York: Simon \& Schuster.

GovTrack.US. 2017. "Falling From First to Last: President Trump has signed the fewest bills into law by this point in a recent president's first year." Located at https://govtrackinsider.com/falling-from-first-to-lastpresident-trump-has-signed-the-fewest-bills-into-law-by-this-point-in$8945 a_{a c 6 a d} 54$ (site last visited on January 27, 2020), December 21.

Hamilton, Alexander, James Madison, and John Jay. 1937. The Federalist. New York: Modern Library.

Heinzerling, Lisa. 2018. "Unreasonable Delays: The Legal Problems (SO Far) of Trump's Deregulatory Binge. Harvard Law \& Policy Review. Vol 12: pp. $13-48$.

Hughes, Trevor. 2016. "Trump calls to 'drain the swamp' of Washington," USA Today. Located at https://www.usatoday.com/story/news/politics/ elections/2016/2016/10/18/donald-trump-rally-colorado-springs-ethicslobbying-limitations/92377656/ (Site lasted visited on February 26, 2020), October 18.

Hurley, Lawrence, and Andrew Chung. 2019. "Trump fumes as Supreme Court blocks census citizenship question." Reuters. Located at https:// www.reuters.com/article/us-usa-court-census/trump-fumes-assupreme-court-blocks-census-citizenship-question-idUSKCN $\mathrm{N}_{1} \mathrm{TS}_{1} \mathrm{BL}$ (site last visited on February 25, 2020). June 27.

Jacobson, Louis. 2018. "PolitiFact: In Number of Bills Signed, Trump Ranks Last." Atlanta Journal Constitution, located at https://www.ajc. com/news/national-govt--politics/politifact-number-bills-signed-trumpranks-last/hBZdhWMV4WF9ST4BDbBRPJ/ (site last visited on January 27, 2020), January 2.

Karson, Kendall. 2020 "Broad disapproval for Trump's handling of coronavirus, race relations," ABC News. Located at https://abcnews. go.com/Politics/broad-disapproval-trumps-handling-coronavirus-racerelations-poll/story?id=71704889 (site last viewed on May 11, 2021) July 10.

Kassop, Nancy. 2020. "Legal Challenges to Trump Administration Policies: The Risk of Executive Branch Lawmaking that Fails to "Take Care."' In Lamb, Charles M., and Jacob R. Nieheisel, Leadership and the Trump Presidency: Executive Power and Democratic Government. Cham, Switzerland: Palgrave, Macmillan, pp. 41-90.
Kennedy, Sheila Seuss, and David Schultz. 2010. American Public Service: Constitutional and Ethical Foundations. Burlington, MA: Jones and Bartlett Publishers, Inc.

Lamb, Charles M., and Jacob R. Nieheisel. 2020. Presidential Leadership and the Trump Presidency: Executive Power and Democratic Government. Cham, Switzerland: Palgrave, Macmillan.

Lantry, Lauren, and Stephaine Ebbs. 2020. "Fauci at odds with Trump: Downplaying virus threat 'not a good thing,' no 'normal' until at least mid-2021," ABC News. Located at https://abcnews.go.com/ Politics/fauci-odds-trump-downplaying-threat-good-thing-normal/ story?id=72952834 (site last viewed on May 11, 2021), September 11 .

McCombs, Brady. 2019. "Trump administration loses bid to dismiss monument lawsuits." Associated Press. Located at https://apnews. com/da291C09181745b592096721bbe72a51 (Site last visited on February 25, 2020), October 1.

McEvoy, Jemima. 2021. "Operation Warp Speed Head Says Trump Administration Responsible For 90\% Of Vaccine Rollout," Forbes. Located at https://www.forbes.com/sites/jemimamcevoy/2021/03/21/ operation-warp-speed-head-says-trump-administration-responsiblefor-9o-of-vaccine-rollout/?sh= 57 cao $82 f_{1} 848$ (site last visited on My 11 , 2021), March 21.

Merchant, Norman, and Kevin Freking. 2020. "US courts rule for border walls both public and private." Associated Press. Located at https:// apnews.com/494015fbbd5422e409cdef048112c1eg (Site last visited on February 25, 2020), January 9.

Michaels, Jon. 2017. Trump and the "Deep State" The Government Strikes Back. Foreign Affairs, 96(5), 52-56.

Mueller, Robert S. III. 2019. Report On The Investigation Into Russian Interference In The 2016 Presidential Election. Washington, D.C.: U.S. Department of Justice.

Neustadt, Richard J. 1964. Presidential Power: The Politics of Leadership. New York: Signet.

Olorunnipa, Toluse, and Beth Reinhard 2020. "Post-impeachment, Trump declares himself the 'chief law enforcement officer' of America." New York Times. Located at https://www.washingtonpost.com/ politics/post-impeachment-trump-declares-himself-the-chief-lawenforcement-officer-of-america/2020/02/18/b8ff49co-5290-11ea-b1194faabac6674f_story.html (Site last viewed on February 25, 2020), February 19.

Oprysko, Caitlin. 2020. "'I don't take responsibility at all': Trump deflects blame for coronavirus testing fumble," Politico. Located at https://www. politico.com/news/2020/03/13/trump-coronavirus-testing-128971 (site last visited on May 11, 2021), March 13. 
Popovich, Nadja Livia Albeck-Ripka and Kendra Pierre-Louis. 2019. "95 Environmental Rules Being Rolled Back Under Trump, New York Times, located at https://www.nytimes.com/interactive/2019/climate/trumpenvironment-rollbacks.html (site last viewed on January 28, 2020), December 21.

Rein, Lisa, and Eric Yoder 2020. Trump issues sweeping order for tens of thousands of career federal employees to lose civil service protections, Washington Post. Located at https://www.washingtonpost.com/ politics/trump-order-federal-civil-service/2020/10/22/c73783fo-148111eb-bc10-40b25382f1be_story.html (site last visited on May 10, 2021), October 22.

Reuters Staff. 2021. "Trump administration had no coronavirus vaccine distribution plan: White House," Reuters. Located at https:// www.reuters.com/article/us-health-coronavirus-usa-klain/trumpadministration-had-no-coronavirus-vaccine-distribution-plan-whitehouse-idUSKBN29ToFY (site last visited on May 11, 2021), January 24.

Rucker, Philip, and Carol Leonnig. 2020. A Very Stable Genius: Donald J. Trump'sTesting of America. New York: Penguin Pres.

Schechter Poultry v. United States, 295 U.S. 495 (1935).

Schier, Steven S. and Todd E. Eberly. 2017. The Trump Presidency: Outsider in the Oval Office. Lanham, MD: Rowman \& Littlefield.

Schultz, David, and Robert Maranto. 1998. The Politics of Civil Service Reform. New York: Peter Lang.

Sexton, Joe. 2019. "Trump, All About Winning, Sees Losses in Court Pile Up." Located at

https://www.propublica.org/article/president-donald-trump-lossesfred-barbash-washington-post-q-and-a (Site last viewed on January 28, 2020), April 2.

Shear, Michael D., et al. 2020. "The Lost Month: How a Failure to Test Blinded the U.S. to Covid-19," New YorkTimes. Located at https://www. nytimes.com/2020/03/28/us/testing-coronavirus-pandemic.html (site last visited on May 11, 2021), March 28.

Shear, Michael D., and Peter Baker. 2019."Key Moments: The Day the House Impeached Trump." New York Times, Located at https://www. nytimes.com/2019/12/18/us/politics/impeachment-vote.html (site last viewed on February 25, 2020), December 18.

Shepardson, David. 2019. "California, other U.S. states sue to block EPA from revoking state emissions authority." Reuters. Located at https:// www.reuters.com/article/us-autos-emissions-california/californiaother-u-s-states-sue-to-block-epa-from-revoking-state-emissionsauthority-idUSKBN1XP25O (Site last viewed on February 25, 2020), November 15.
Skowronek, Stephen. 2008. Presidential Leadership in Political Time: Reprise and Reappraisal. Lawrence, KS: University Pres of Kansas.

Thompson, Frank J. Kenneth K. Wong, and Barry G. Rabe. 2020. Trump, the Administrative Presidency, and Federalism. Washington, D.C.: Brookings.

Trump, Donald J, and Tony Schwartz. 2015. The Art of the Deal. New York: Ballantine Books.

Trump, Donald J. 2016. "Donald Trump 2016 RNC draft speech transcript," Politico. Located at https://www.politico.com/story/2016/07/ full-transcript-donald-trump-nomination-acceptance-speech-atrnc-225974 (site last visited on September 4, 2021) (July 21, 2106).

Trump, Donald J. 2017. "President Trump's Inaugural Address, Annotated." Located at https://www.npr.org/2017/01/20/510629447/ watch-live-president-trumps-inauguration-ceremony (Site last visited on September 4, 2021 (January 20, 2017).

Trump v. Hawaii, 585 U.S. __ (2018),

Wilson, James Q. 1989. Bureaucracy: What Government Agencies Do And Why They Do It. New York: Basic Books.

Wolff, Michael. 2018. Fire and Fury. New York: Henry Holt and Company. Woodward, Bob. 2020. Rage. New York: Simon and Schuster.

Youngstown Sheet and Tube v. Sawyer, 343 U.S. 579 (1952). 